\title{
Role of a dynamic LVOT obstruction in the pathogenesis of takotsubo syndrome
}

\author{
Jan Pavlovič', Karel Hlaváček'1, Rudolf Feuereisl', Roman Surovčík', Petr Frídl'1, Ondřej Myslivec², František \\ Pad'our', Pavel Jebavý ${ }^{1}$ \\ 'Kardiologie na Bulovce, s. r. o., Prague, \\ ${ }_{2}^{25 t}$ Department of Internal Medicine, University Hospital Na Bulovce, Prague, Czech Republic
}

Pavlovič J, Hlaváček K, Feuereisl R, et al. Role of a dynamic LVOT obstruction in the pathogenesis of takotsubo syndrome. Cor Vasa 2010;52:695-699.

Aims: To explore the possible causative relationship between a dynamic left ventricular outflow tract (LVOT) obstruction and takotsubo syndrome.

Methods and results: We analyzed a group of eleven patients with takotsubo syndrome. In this article, we focus on one patient developing a less common variant of takotsubo (stress) syndrome after a situation creating a decreased preload, but without a preceding stressful event (either psychological or physical). Coincidently we found a dynamic obstruction of left ventricular outflouw tract and septal bulge mimicking the pattern of hypertrophic cardiomyopathy. After the contraction abnormalities had normalized, we performed a provocation test with nitroglycerin on follow-up inducing the obstruction. An exercise stress test performed on follow-up showed a good effect of conservative treatment.

The relevant literature was reviewed.

Conclusion: We suggest a possible primary pathogenetic role of a dynamic LVOT obstruction in the development of takotsubo syndrome. Key words: Takotsubo syndrome - LVOT obstruction - Septal bulge - Hypertrophic cardiomyopathy

Pavlovič J, Hlaváček K, Feuereisl R, et al. Úloha dynamické obstrukce LVOT v patogenezi tako-tsubo syndromu. Cor Vasa 2010;52:695-699.

Cíl: Zjistit možnou přičinnou souvislost mezi dynamickou obstrukcí LVOT a tako-tsubo syndromem.

Metodika a výsledky: Analyzovali jsme skupinu jedenácti pacientů s tako-tsubo syndromem. $V$ tomto článku zaměřujeme pozornost na pacientku, u které se rozvinula méně častá varianta tako-tsubo syndromu v souvislosti se situací vytvářející snížení preloadu, přičemž nepředcházela žádná stresová událost (psychická ani fyzická). Současně byla zjištěna dynamická obstrukce výtokového traktu levé komory a septum sigmoideum imitující obraz hypertrofické kardiomyopatie. Jakmile došlo k plné úpravě všech poruch kontraktility, provedli jsme, při ambulantní kontrole, provokační test s nitroglycerinem a vyvolali jsme obstrukci výtokového traktu levé komory. Ergometrie provedená s odstupem při ambulantní kontrole potvrdila dobrý účinek konzervativní léčby.

Shromáždili jsme a prostudovali tematicky související literaturu.

Závěr: Ukazujeme na možnou primární patogenetickou úlohu dynamické obstrukce výtokového traktu levé komory v rozvoji tako-tsubo syndromu.

Klíčová slova: Tako-tsubo syndrom - Obstrukce LVOT - Septal bulge - Hypertrofická kardiomyopatie

Address: MUDr. Jan Pavlovič, Kardiologie na Bulovce, s. r. o., Na Truhlářce 62, 18085 Prague 8, Czech Republic, e-mail: JanPavlovic@ seznam.cz

\section{Introduction}

Takotsubo syndrome is a clinical entity which was first described in Japan in $1991^{1}$ and received almost no attention in the Western world until 2001. ${ }^{2}$ A sizable literature has been published since then and today it is possible to make rough estimates of the prevalence of this disorder: it is probably around $1 \%$ of the patients referred for suspected acute coronary syndrome (ACS).

This disorder affects mostly women (more than $80 \%$ ). It is typically triggered by an extraordinary stress event, either psychological or physical. The symptoms mimic acute coronary syndrome, but coronary angiograms are either normal or with insignificant findings or findings that do not explain the motion abnormalities. Ventriculography shows these patients have typical defects of left ventricle (LV) movement, with preserved contractility of the basal segments (and apex in a minority of cases) and akinesis of the remaining segments. The most common ECG findings are elevations of the ST segments, ST depressions and T wave inversions. Cardiac biomarkers are usually mildly elevated. The prognosis is favourable. There is, as a rule, complete resolution of all abnormalities within 2-3 weeks even though the patient can be initially in a serious state, including pulmonary edema or cardiogenic shock. Recurrence of this syndrome appears rare. 
The pathogenesis of takotsubo syndrome has not been satisfactorily explained to this day. The most widely accepted theory is that of a catecholamine surge which leads to a transitory impairment of contractility resembling stunned myocardium. But the precise mechanism remains unknown. All the theories (direct catecholamine toxicity, myocarditis, obstruction of left ventricular outflow tract - LVOT) postulated to date remain speculative explanations of this disorder. It seems that more new questions arise for every question that has been answered. The only fact that seems unambiguous is the involvement of catecholamines in the pathogenesis.

In this short article we are focusing on the LVOT obstruction and septal bulge and we will join the discussion regarding the role of the dynamic LVOT obstruction in the pathogenesis of stress cardiomyopathy. Specifically, is it involved or could it even be the primary cause?

\section{Materials and methods}

We have analyzed a population of 2143 patients admitted to our institution between years 2004 and 2009 for suspected $\mathrm{ACS}^{3}$ and found 11 patients who met the revised Mayo Clinic's diagnostic criteria. ${ }^{4,5}$

Most of our patients underwent dobutamine stress echocardiography three months or more after discharge. ${ }^{3}$

In this paper we closely analyze the case of a 60 -yearold woman, treated half a year for hypertension, who was admitted for presyncope accompanied by mild dyspnoea and tremor. Onset of symptoms occurred when she was lifting a bucket with water after ten minutes of standing. She had never experienced such symptoms before. It was preceded by a six-month history of fatigue, decreased exercise tolerance and dyspnoea on exertion (NYHA Class II). She admitted chronic, low fluid intake. There were no symptoms of infectious disease preceding her sudden illness and the laboratory signs of inflammation were not elevated on admission. Her blood pressure on admission was 100/50. The ECG showed an rS pattern in V1-3, left axis of +30 degrees, there was no significant denivelisation of ST segment, only $\mathrm{T}$ wave inversion in leads III and aVF. Her troponin I and CKMB values were mildly elevated. A slightly elevated blood urea, which subsequently normalized after fluid replacement, confirmed an insufficient state of hydration. The transthoracic echocardiography showed marked defects of contractility and significantly reduced LV systolic function (left ventricular ejection fraction, LVEF, 40\%). At the same time hypertrophy of the basal septum $(16 \mathrm{~mm})$, systolic anterior motion of mitral valve with moderate mitral regurgitation and pressure gradients across the LVOT of $75 \mathrm{mmHg}$ at rest and $167 \mathrm{mmHg}$ after an extrasystole were detected. There was also a small pericardial effusion. Septal morphology (Figure 1) satisfied the anatomical criteria of hypertrophic cardiomyopathy, ${ }^{6}$ but since we did not perform myocardial biopsy that would confirm this diagnosis, we describe it as septal bulge mimicking the pattern of hypertrophic cardiomyopathy. There was a normal finding on the coronary angiography (Figures $2 \mathrm{~A}, 2 \mathrm{~B}$ ) and the ventriculography

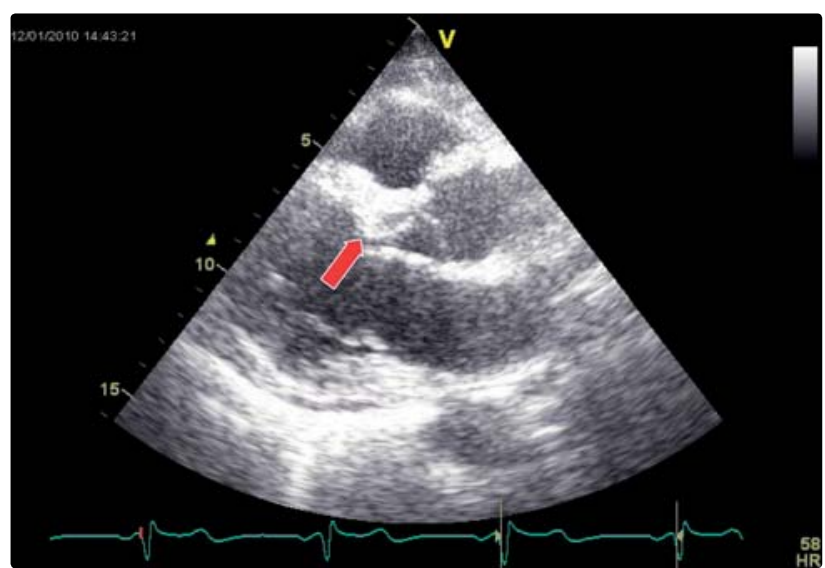

Figure 1 Transthoracic echocardiography, parasternal long axis view with noticeable septal bulge - arrow

(Figures 3A, 3B) showed akinesis of the mid-segments of the left ventricle with compensatory hypercontractility of the basal segments, and preserved contractility of the apex, which is consistent with a less common variant of takotsubo syndrome. Subsequent hemodynamic examination revealed borderline pressure in the pulmonary artery (PA) (mean PA pressure $23 \mathrm{mmHg}$ ), elevated LV end-diastolic pressure (19 $\mathrm{mmHg}$ ), and no pressure-gradient across LVOT at rest. However, there was a gradient of $24 \mathrm{mmHg}$ after provocation with intravenous nitroglycerin. Then the patient was treated with a beta-blocker, ACE inhibitor, acetylsalicylic acid, and, because of hypertension, a dihydropyridine calcium channel blocker. She underwent a series of echocardiographic controls showing continuous improvement of LV function until it was fully normalized on discharge on the $13^{\text {th }}$ day of hospitalization.

We again performed echocardiography at follow up one week after discharge. There was completely normal contractility of the left ventricle, borderline pressure in the pulmonary artery, and no pressure gradient across LVOT at rest. After a challenge with nitroglycerin we provoked a maximum pressure gradient across LVOT of $42 \mathrm{mmHg}$ (Figures 4A, 4B).

\section{Results}

We found three patients in our group of eleven with takotsubo syndrome (TTS) having septal bulge (with sizes varying from 13 to $16 \mathrm{~mm}$ ), but in none of them was an LVOT obstruction detected, except for the patient presented in this article.

This patient showed significant subjective improvement of exercise tolerance after discharge using the medication regimen mentioned above with increased fluid intake. Her improvement was verified by a bicycle stress test on follow up one month after discharge.

There has been no recurrence of TTS in our group of patients to date.

Eight patients of this group underwent dobutamine stress echocardiography and no motion abnormality was induced. ${ }^{3}$ 

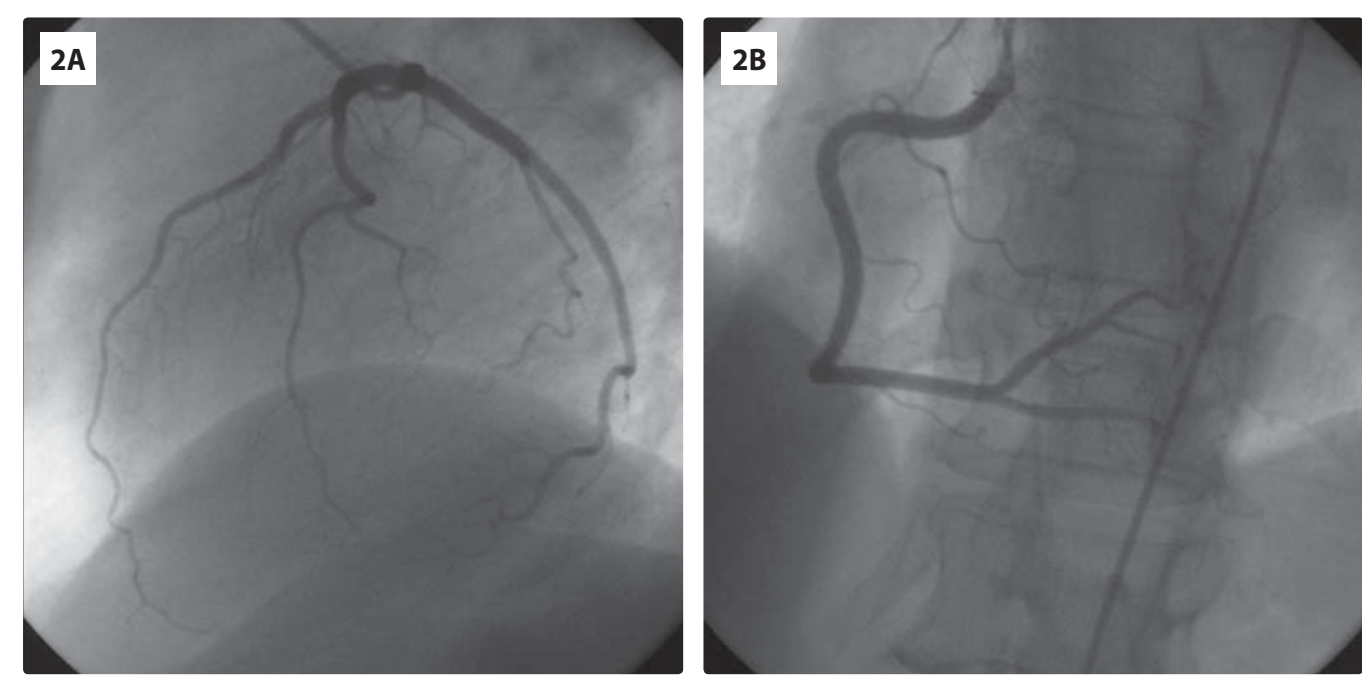

\section{Discussion}

We believe that our observation, consistent with other authors, ${ }^{7,8}$ is not just a coincidence and that the primary cause of TTS can be LVOT obstruction. We offer the following arguments for this claim:

1. History is suggestive of LVOT obstruction that was subsequently confirmed echocardiographically and by catheterisation after provocation with nitroglycerin.

2. The triggering stress event is missing (either psychological or physical). Hence, if catecholamines are at play, their role in pathogenesis might be secondary and not primary.

3. The gradient across the LVOT disappeared within hours and was not present despite the hypercontracitility of basal segments. Thus, the basal hypercontractility by itself did not cause the obstruction. This was confirmed with follow-up echocardiography: When the contractility had normalized, the gradient of $42 \mathrm{mmHg}$ was provoked by nitroglycerin.

4. The history of decreased exercise tolerance suggests that the dynamic obstruction of LVOT could have been asserting itself for several months before and led to a moment when the left ventricle no longer resisted the increased afterload and became "stunned". This idea
Figure 2 Coronary angiography (A) left coronary artery, (B) right coronary artery is supported by the improved exercise tolerance on conservative treatment.

Dynamic obstruction of LVOT was observed in acute myocardial infarction with akinesis of anteroapical wall ${ }^{9}$ and in stress takotsubo syndrome without hypertrophic cardiomyopathy ${ }^{2,10}$ as well. The role of LVOT obstruction in the development of TTS has been hypothesized since 2003. ${ }^{7}$ The authors propose that in some patients with geometric predisposition (e.g. sigmoid septum), LVOT obstruction can occur in certain conditions, such as intense adrenergic stimulation or hypovolaemia. The obstruction causes elevated left ventricular filling pressures, increasing myocardial oxygen demand and leads to hypoperfusion and ischaemia.

The idea has been elaborated on by Merli et $\mathrm{al}^{8}$ who presented a series of four patients. According to this work, obstruction leads to a division of LV into two parts, with high and lower pressure. With high pressure there is a high wall stress, subendocardial ischaemia which is further worsened by concomitant catecholamine release increasing the myocardial oxygen demand and contractility disorders ensue.
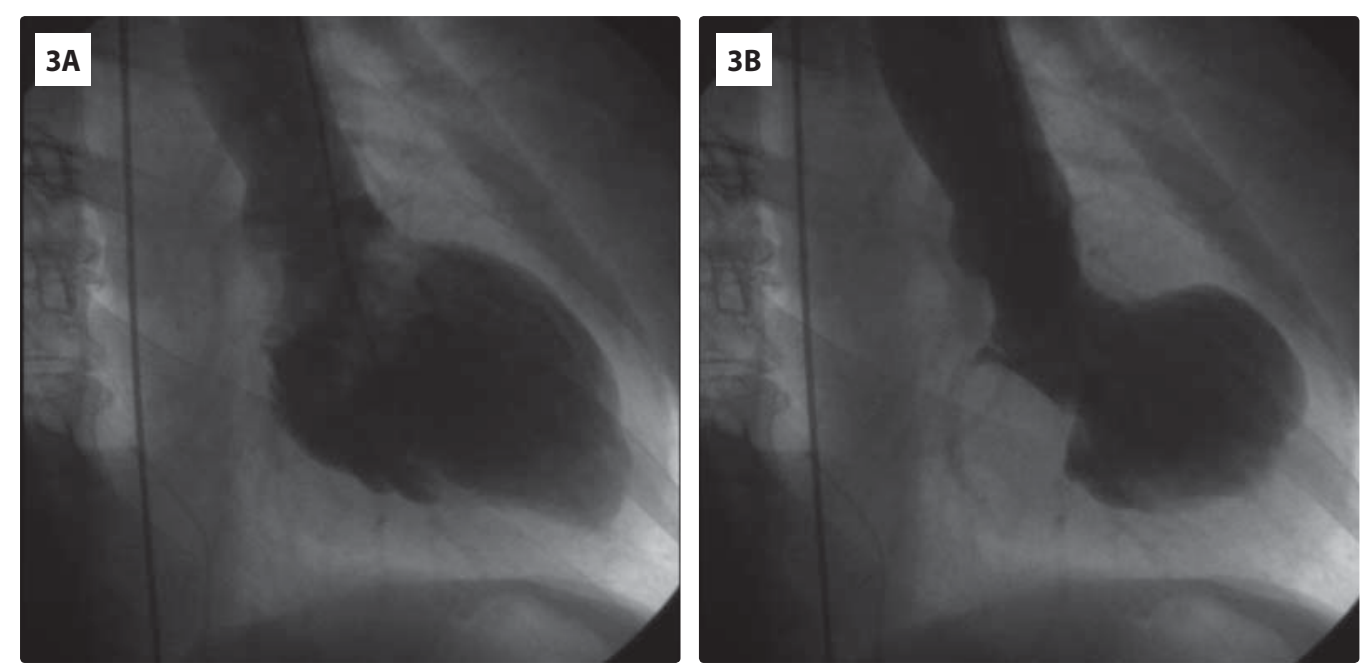

Figure 3 Left ventriculography (A) diastole, (B) systole 

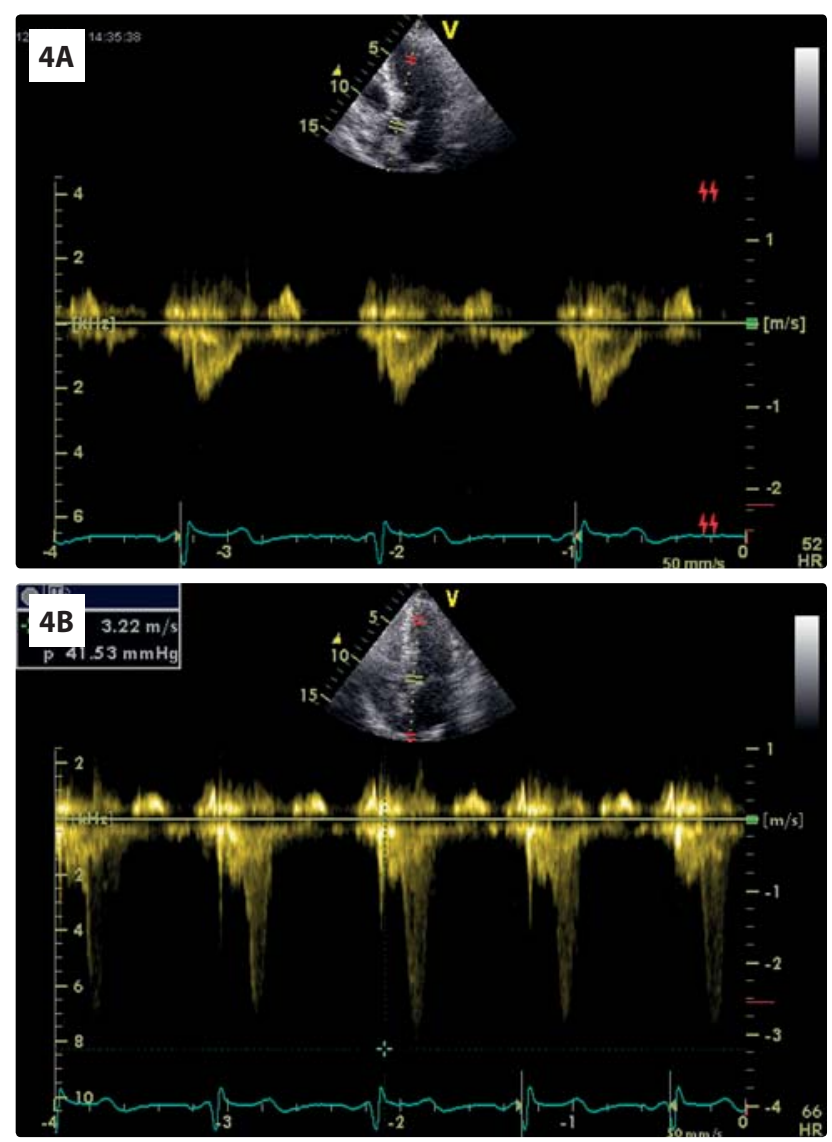

Figure 4 CW Doppler examination of LVOT (A) at rest, (B) after the nitroglycerin challenge

There have been two observational prospective studies concerning the LVOT obstruction with contribution of septal bulge and its role in the development of TTS. ${ }^{11,12}$ In both studies the prevalence of septal bulge was $100 \%$ in patients with TTS and LVOT obstruction. In the first study ${ }^{11}$ half of the patients had significant left ventricular hypertrophy (LVH). The obstruction gradient was detected in $58.8 \%$ of patients with $\mathrm{LVH}$ and $0 \%$ in the group without LVH. In the latter study ${ }^{12} 25 \%$ (eight female patients) of all patients with TTS exhibited LVOT obstruction and, once again: the prevalence of septal bulge was $100 \%$ in patients with LVOT obstruction. Both studies were inconclusive in terms of finding clear evidence for either primary or secondary role of LVOT obstruction in pathogenesis of TTS. Nevertheless, the fact that the septal bulge and the intraventricular gradient occurred in a substantial proportion of patients with TTS, and that the septal bulge was actually a condition for obstruction to occur, is in our opinion impressive and strongly suggests the possibility of involvement of sigmoid septum in the pathogenesis of TTS. But as the majority of patients with TTS have no LVOT obstruction or septal bulge, it appears clear that LVOT obstruction cannot be the only cause of TTS.

In the patients of Merli et al there is evidence of physical stress before the onset of symptoms. In comparison, our patient explicitly denied the occurrence of a preceding stressful event. We do not believe it was physically stressful for her to lift a six-kilogram bucket. She claimed to frequently work harder than this. We believe that the triggering moment could have been a combination of a decreased preload due to an insufficient state of hydration, and a decreased venous return during standing and, finally, an analogous variant of the Valsalva maneuver, i.e., the lifting of the bucket. This combination led to decreased LV filling and the dynamic obstruction with the septal bulge took place. Transient dynamic obstruction of LVOT itself could cause the catecholamine release (possibly via activation of arterial baroreceptors) with the resulting increase of stress in the LV wall, diffuse subendocardial ischaemia and a subsequent defect in the movement of LV resembling stunned myocardium.

The occurrence of an intraventricular gradient caused by hypercontractility of basal segments without the contribution of septal hypertrophy has been described. ${ }^{2,10}$ During catheterisation of our patient, however, the gradient was not present despite the hypercontractility of the basal segments and it occurred only after provocation with intravenous nitroglycerin, i. e., in a situation mimicking the assumed triggering event, the decreased preload.

Not surprisingly, there are some caveats that should also be considered: Specifically, we are not able to explain why TTS has not been more frequently described in other conditions creating increased afterload, why the contractility of the LV apex in our patient remained spared (was it because of dual artery supply?) or why there is such scarce evidence of recurrent takotsubo syndrome - to our knowledge only case-study reports have been described.

It is likely, that with larger samples, systematic searching for the LVOT obstruction and periodical echocardiographic check-ups could provide the evidence necessary to verify this theory. Undoubtedly this line of research will continue and we look forward to learning the answers to the questions that have been raised.

\section{Conclusion}

This article is a contribution to the discussion about pathogenesis of takotsubo syndrome which is far from being resolved. It offers evidence of a possible primary pathogenetic role of the dynamic LVOT obstruction caused, in our case, by septal bulge and decreased preload.

\section{Literature}

1. Dote K, Sato H, Tateishi H, et al. Myocardial stunning due to simultaneous multivessel coronary spasms: A review of 5 cases. J Cardiol 1991;21:203-214.

2. Tsusihashi K, Ueshima K, Uchida T, et al. Transient left ventricular apical ballooning without coronary artery stenosis: a novel heart syndrome mimicking acute myocardial infarction. J Am Col Cardiol 2001;38:11-18.

3. Surovčík R, Feuereisl R, et al. Stresová (takotsubo) kardiomyopatie. Interv Akut Kardiol 2009;8:292-296.

4. Kawai S, Kitabake A, Tomoike H. Guidelines for diagnosis of takotsubo (ampulla) cardiomyopathy. Circulation J 2007;71:990-992.

5. Prasad A, Lerman A, Rihal CS. Apical ballooning syndrome (Tako-Tsubo or stress cardiomyopathy): a mimic of acute myocardial infarction. Am Heart J 2008;155:408-417. 
6. Barry J. Marron. Hypertrophic cardiomyopathy: A systematic review. JAMA 2002;287:1308-1320.

7. Penas Lado M, Barriales-Villa R, Goicolea J. Transient left ventricular apical ballooning and outflow tract obstruction. J Am Coll Cardiol 2003;42:11431144

8. Merli E, Sutcliffe S, Gori M, et al. Tako-Tsubo cardiomyopathy: New insights into the possible underlying pathophysiology. Eur J Echocardiogr 2006;7:53-61.

9. Haley JH, Sinak LJ, Tajik AJ, et al. Dynamic left ventricular outflow tract obstruction in acute coronary syndromes: an important cause of new systolic murmur and cardiogenic shock. Mayo Clin Proc 1999;74:901-906.
10. Villareal RP, Achari A, Wilanski S, Wilson JM. Anteroapical stunning and left ventricular outflow tract obstruction. Mayo Clin Proc 2001;76:79-83.

11. Núñez-Gil IJ, García-Rubira JC, Luaces M. Outflow tract obstruction and Takotsubo syndrome. Am Heart J 2009;158:e5-e6.

12. El Mahmoud R, Mansencal N, Pilliére R, et al. Prevalence and characteristics of left ventricular outflow tract obstruction in Tako-Tsubo syndrome. Am Heart J 2008;156:543-548.

Received 15. 3. 2010 